\title{
Effect of Casting Conditions on Physical Properties of Some Experimental Partial Denture Alloys*
}

\author{
KAMAL ASGAR, BRUCE TECHOW, F. C. ALLAN, and L. V. \\ SUTFIN, Dental Materials Department, University of Michigan, Ann \\ Arbor, Michigan 48104
}

\begin{abstract}
Summary
Four alloys were tested which are being considered for use in making partial denture castings. The procedure was varied by using three spruing methods, two different waxes, two melt temperatures, and two different directions of filling. Statistical analysis techniques were used to determine the significance of the results. Spruing method was the most highly influencial of the variables and the flat method gave the best results. This method also is most relevant to clinical procedure. The effect of temperature, in fewer instances, was also influential. At a lesser level of signifiacnce direction of filling, and in one instance wax, had an effect.
\end{abstract}

\section{INTRODUCTION}

The process of preparing a Co-Cr partial denture casting from the original impression taken in the mouth is very exacting. During each step of the preparations, many variables can operate to affect the finished product.

In order to fit in the mouth, the casting must fulfill certain requirements. Not only must physical properties be adequate; in addition, the surface must be smooth and the final casting should closely approximate the dimensions of the original pattern. Thus, the investment must have a certain per cent expansion and this must be known for the range of temperatures being considered. ${ }^{1}$ Also, the per cent shrinkage of the metal must be known.

* Presented at the 46th General Meeting of the International Association for Dental Research, Washington, D.C., March 1967. 
Earnshaw ${ }^{2}$ has studied extensively the expansion of various investments during setting, heating, and cooling. Dootz et al. ${ }^{3}$ studied this area while using the actual partial denture cast. Other investigators also have contributed to various aspects of this area. Carter and Kidd ${ }^{4}$ have reported the influence of casting variables on the dimensions of the metal. Earnshaw also has studied casting shrinkage of $\mathrm{Co}-\mathrm{Cr}$ alloys. ${ }^{5,6}$

Also, the metal can react with the investment during the casting procedure. If the reaction is serious enough, the surface will be marred so that excessive polishing will be necessary to obtain the smooth surface required for use in the mouth, and the dimensional limits will be exceeded. Asgar and Peyton ${ }^{7}$ have found that casting of an overheated melt resulted in an unacceptable surface. Further work by Allan and Asgar ${ }^{8}$ has shown the effect of the investment in this interface reaction. Other factors involved in surface reaction are the composition of the melt, temperature of the melt, and temperature of the mold.

Although the above-mentioned variables are usually the objective of most investigations, the finished casting can also be affected by other factors. The type of wax used for forming the pattern can add contaminants to the system. Also the atmosphere in which the metal is heated and cast can react with the molten metal causing contamination. $^{9,10}$ On the other hand, reducing the atmosphere (i.e., vacuum) can also affect the composition and solubility of elements in the melt. ${ }^{10-12}$

The concern with the variations of all these factors is their influence on the properties of the cast alloy. Again, extensive programs have been carried out on the properties of $\mathrm{Co}-\mathrm{Cr}$ alloys ${ }^{13-17}$ and of the cast denture. ${ }^{18}$ In order to improve the mechanical properties, heat treatment has been tried, ${ }^{19-21}$ but with limited success. In the same vein, the cooling rate has been varied. ${ }^{19}$

Recently, the effect of additional elements has been studied quite extensively. ${ }^{22-26}$ Several new alloys have been studied, ${ }^{27,28}$ some applicable in dentistry..$^{28,29}$

Since a variation in forming will give different results for properties, the samples for testing should be prepared uniformly. The spruing setup will determine which portion will fill first and solidify first. This, in turn, determines the grain size and the distribution of phases. 
All these variables have been considered before. Some have been the object of detailed investigation. The effect of other variables has been conjecture. However, in a system such as this, can one variable be isolated from the rest? The importance of each variable in the system must be defined and the interrelationships between the variables must be determined. These considerations have been the goal of our investigation.

In this study test samples were prepared under predetermined conditions. Then the mechanical properties of these samples were obtained. These values were coded into a computer program and statistical analysis techniques were applied. Thus, not only were the mechanical properties obtained, but also the significance of each of the variables mentioned above was determined.

\section{EXPERIMENTAL}

\section{Variables Considered}

The stages of making the casting were studied, and each possible variation in the procedure and choice of materials was noted. These variables are presented and explained in Table I. (Table II gives the casting temperatures.) The compositions and sources of the alloys are given in Table III.

\section{Laboratory Procedure}

Forty samples were cast for each alloy. The samples were waxedup and cast following normal dental techniques. Figure 1 describes the spruing methods. V-R investment (Austenal Dental Division of Howmet Corp., Chicago, Illinois) was used. The mold was burned out at $1600^{\circ} \mathrm{F}$ for an hour and was cast into at this temperature. Casting was done under a reduced atmosphere. All the castings were bench-cooled in the mold.

After the investment had been broken off, the condition of the sample surface was noted. Then the sample was sandblasted and the threaded ends machined to fit the sample holder. The shape and dimensions of the test sample follow ADA specifications.* The soundness of the sample was checked by x-ray before pulling and a

* Figure 14-1 in ADA Guide to Dental Materials, p. 124. 
TABLE I

All Variables Considered

A. Position when filling

1. Left (metal enters first)

2. Right (metal enters second)

B. Temperature (see Table II)

1. Metal
(a) normal
(b) overheat

2. Mold (held constant ${ }^{a}$ )

3. Cooling Rate (held constant

C. Contamination sources

1. Wax
(a) industrial
(b) dental

2. Atmosphere (held constant ${ }^{a}$ )

3. Investment (held constant ${ }^{\text {a }}$ )

D. Spruing method ${ }^{\mathrm{a}}$

1. Feed

2. Vent

3. Flat

E. Alloy type

1. 17-7

2. HS-21

3. HS-31

4. Multimet

a See text for details.

TABLE II

Casting Temperatures of Alloys

\begin{tabular}{lcc} 
& Normal, $^{\circ} \mathbf{F}$ & Overheat, ${ }^{\circ} \mathbf{F}$ \\
\hline $17-7$ & $2900-3000$ & $3100+$ \\
HS-21 & $\sim 2700$ & $2900+$ \\
HS-31 & 2900 & $3100+$ \\
Multimet & $\sim 2800$ & $\sim 3000$ \\
\hline
\end{tabular}




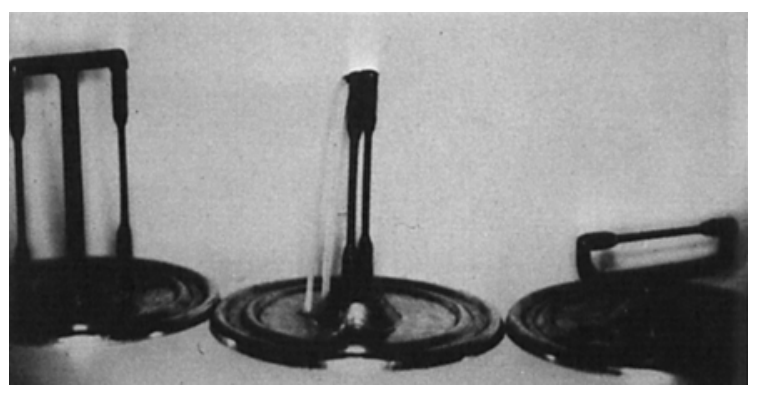

Fig. 1. Spruing of wax patterns. From left to right: vent type, feed type, and flat type.

TABLE III

Compositions of Alloys

\begin{tabular}{lllll}
\hline Element & $17-7^{\mathrm{a}}$ & HS21 & HS31 & Multimet \\
\hline $\mathrm{Cr}$ & 16.9 & 27.4 & 24.8 & $20.0-22.5$ \\
$\mathrm{Co}$ & & bal. & bal. & $18.5-21.0$ \\
$\mathrm{Ni}$ & 7.3 & 2.51 & 10.5 & $19.0-21.0$ \\
$\mathrm{Fe}$ & bal. & 1.67 & 1.65 & bal. \\
$\mathrm{W}$ & & & 7.54 & $2.0-3.0$ \\
$\mathrm{C}$ & 0.071 & 0.27 & 0.48 & $0.08-0.16$ \\
$\mathrm{Si}$ & 0.32 & 0.68 & 0.72 & 1.0 \\
$\mathrm{Mo}$ & & 5.45 & & $2.5-3.5$ \\
$\mathrm{Mn}$ & 0.49 & 0.69 & 0.78 & $1.0-2.0$ \\
$\mathrm{~B}$ & & $0.001^{\mathrm{d}}$ & & \\
$\mathrm{Al}$ & 1.15 & & & 0.016 \\
$\mathrm{P}$ & 0.018 & & 0.011 & \\
$\mathrm{~S}$ & 0.007 & & & $0.75-1.25$ \\
$\mathrm{Cb}$ & & & & $0.1-0.2$ \\
$\mathrm{Ta}$ & & & & 0.1 \\
$\mathrm{~N}$ & & & & \\
$\mathrm{Be}$ & & & & \\
\hline
\end{tabular}

a Certified chemical analysis of wire as received, Viking Steel Co., Cleveland, Ohio.

b Certified chemical analysis of remelt shot as received, Union Carbide Corp., Stellite Div., Kokomo, Ind.

- Multimet Alloy (brochure) March 1962, p. 4, source as in footnote b.

d Less than. 


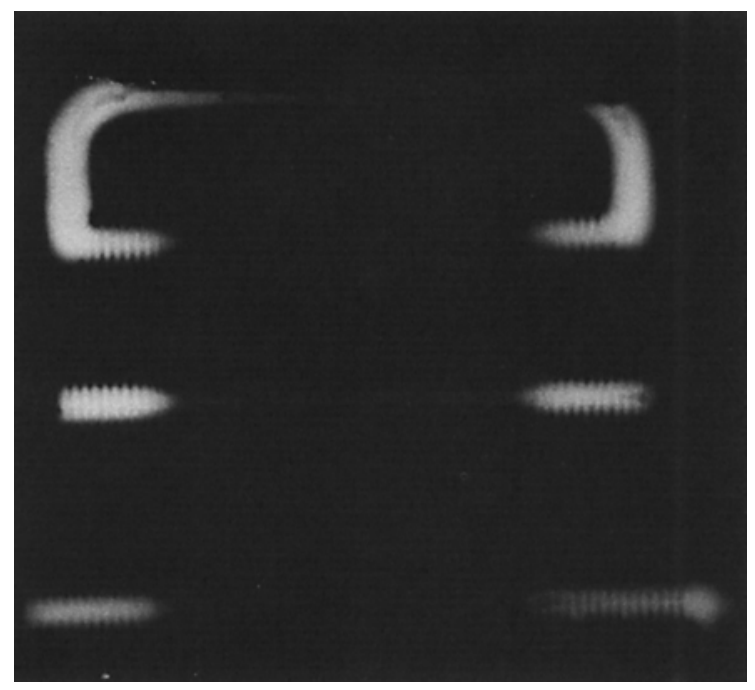

Fig. 2. X-ray of specimens taken before testing for the physical properties.

typical radiograph is shown in Figure 2. The samples were pulled in a Riehle lesting machine. The mechanical properties that were obtained were ultimate tensile strength. $0.1 \%$ yield point, and elongation.

\section{Analysis of Data}

The statistical analysis consisted of several different analysis of variance tests and computation of means and of standard deviations. To reduce the burden of hand calculation an analysis of variance program $\dagger$ and a standard statistical program $\ddagger$ were used on an IBM 7090 computer to do the statistical calculations.

A factorial design was set up to study the variables. Each variable was divided into one or more levels. The variables, called factors, and levels considered are listed in Table IV. The alloy composition also was a variable but since the alloys were so obviously different, in this phase of the investigation, no comparison was made from the viewpoint of the composition.

$\dagger$ This program was written by Dr. J. Lingoes, Assoc. Prof. of Psych. and Res. Assoc., Computing Center, Univ. of Michigan.

$¥$ This program, called STCP07, is in the tape library of the University of Michigan 7090 IBM computer. 
TABLE IV

Factorial Design

\begin{tabular}{ll}
\hline Factor & \multicolumn{1}{c}{ Level } \\
\hline (1) Pattern & (1) Feed \\
& (2) Vent \\
& (3) Flat \\
(2) Temperature & (1) Normal \\
(3) Wax & (2) Overheat \\
(4) Direction & (1) Dental \\
& (2) Industrial \\
& (1) Right \\
& (2) Left \\
\hline
\end{tabular}

The first two types of spruing patterns included the factor of direction, but the horizontal spruing pattern (due to its design) did not include the factor of direction.

Two analysis of variance tests were conducted. First the analysis was run considering all factors. $F$-values were considered and the significant points of variation were noted. Then $t$-tests were run since the $F$-test could not differentiate among the spruing methods and the $t$-test gives more detailed evaluation.

Then the factor of pattern was neglected and an analysis was conducted for each type of pattern. Hence, the effects of temperature, wax, and direction were determined without the influence of spruing method.

At all points where a significant difference in properties was indicated, the actual properties were determined. The analysis of variance technique simply indicates that a difference in values exists, it does not point out which value is better. Also, the overall means for the properties were determined to give some basis of comparison with properties normally obtained with these alloys.

\section{RESULTS}

The first test run was an analysis of variance for all factors as shown in Table IV. The results for the $F$-value tests are given in Table V. Spruing method was highly significant in all instances and in certain cases temperature of casting was significant. 
TABLE V

Results from F-Tests on Analysis of All Factors

\begin{tabular}{|c|c|c|c|c|c|c|}
\hline \multirow[b]{2}{*}{$17-7$} & \multicolumn{2}{|c|}{ UTS } & \multicolumn{2}{|c|}{$0.1 \%$ yield } & \multicolumn{2}{|c|}{ Elongation } \\
\hline & $\begin{array}{l}\text { Sprue }^{b} \\
\text { Temp }^{c}\end{array}$ & $\begin{array}{l}F=7.26 \\
F=4.6\end{array}$ & 3 Sprue $^{\text {b }} F$ & $F=10.8$ & Sprue $^{b} \quad F=$ & $=6.2$ \\
\hline HS-21 & Sprue ${ }^{b}$ & $F=18.9$ & $\begin{array}{ll}\text { Sprue }^{c} & F \\
\text { Temp }^{c} & F\end{array}$ & $\begin{array}{l}F=4.52 \\
F=5.4\end{array}$ & $\begin{array}{ll}\text { Sprue }^{\mathrm{b}} & F= \\
\text { Temp }^{\mathrm{c}} & F=\end{array}$ & $\begin{array}{l}=6.7 \\
=4.2\end{array}$ \\
\hline HS-31 & Sprue ${ }^{b}$ & $F=42.3$ & $\begin{array}{ll}\text { Sprue }^{\mathrm{b}} & F \\
\text { Temp }^{\mathrm{b}} & F\end{array}$ & $\begin{array}{l}F=5.97 \\
F=27.7\end{array}$ & Sprue $^{\mathrm{b}} \quad F=$ & $=30.6$ \\
\hline \multicolumn{7}{|c|}{$\begin{array}{l}\text { For Sprue } d f^{\mathrm{a}}=2 / 45 \\
\text { For Temp } d f=1 / 46 \\
F_{99}=5.12 \text { for } d f=2 / 45 \\
F_{99}=7.24 \text { for } d f=1 / 46 \\
F_{95}=4.17 \text { for } d f=1 / 46\end{array}$} \\
\hline \multicolumn{7}{|c|}{$\begin{array}{l}\text { \& } d f \text {, degrees of freedom. } \\
\text { b Indicates factor is significant at } 99 \% \text { level. } \\
\text { - Indicates factor is significant at } 95 \% \text { level. }\end{array}$} \\
\hline \multicolumn{7}{|c|}{$\begin{array}{c}\text { TABLE VI } \\
\text { Results of } t \text {-Tests on Analysis of All Factors }\end{array}$} \\
\hline & \multicolumn{2}{|c|}{ UTS } & \multicolumn{2}{|c|}{$0.1 \%$ yield } & \multicolumn{2}{|c|}{ Elongation } \\
\hline $17-7$ & $\begin{array}{l}\text { Feed-Vent } \\
\text { Feed-Flat } \\
\text { Temp }^{\mathbf{b}, c}\end{array}$ & $\begin{aligned} t & =3.05 \\
t & =3.6 \\
t & =2.15\end{aligned}$ & $\begin{array}{l}\text { Feed-Flat } \\
\text { Vent-Flat }^{b}\end{array}$ & $\begin{array}{l}t=4.6 \\
t=3.0\end{array}$ & $\begin{array}{l}\text { Feed-Flat } \\
\text { Vent-Flat }^{\mathbf{a}, \mathbf{c}} \\
\text { Direction }^{\mathbf{a}, \mathbf{c}}\end{array}$ & $\begin{aligned} t & =3.0 \\
t & =2.38 \\
t & =1.99\end{aligned}$ \\
\hline HS-21 & $\begin{array}{l}\text { Feed-Ventb } \\
\text { Feed-Flat } \\
\text { Vent-Flat }^{a, c}\end{array}$ & $\begin{array}{l}t=3.5 \\
t=6.6 \\
t=2.22\end{array}$ & $\begin{array}{l}\text { Feed-Vent } \\
\text { Feed-Flat } \\
\text { Temp } \\
\text { Temo }\end{array}$ & $\begin{aligned} t & =3.1 \\
t & =2.06 \\
t & =2.31\end{aligned}$ & $\begin{array}{l}\text { Feed-Flat }^{\mathbf{b}} \\
\text { Vent-Flat }^{\mathbf{a}, \mathbf{c}} \\
\text { Temp }^{\mathrm{a}, \mathrm{o}}\end{array}$ & $\begin{aligned} t & =3.9 \\
t & =1.93 \\
t & =2.06\end{aligned}$ \\
\hline HS-31 & $\begin{array}{l}\text { Veed-Vent } \\
\text { Feed-Flat } \\
\text { Vent-Flat }^{b}\end{array}$ & $\begin{array}{l}t=4.7 \\
t=9.3 \\
t=4.4\end{array}$ & $\begin{array}{l}\text { Feed-Flatb } \\
\text { Vent-Flatb } \\
\text { Temp }^{b}\end{array}$ & $\begin{array}{l}t=2.82 \\
t=2.93 \\
t=5.3\end{array}$ & $\begin{array}{l}\text { Feed-Vent }{ }^{b} \\
\text { Feed-Flat }{ }^{b} \\
\text { Vent-Flat }^{b}\end{array}$ & $\begin{array}{l}t=5.0 \\
t=7.1 \\
t=3.78\end{array}$ \\
\hline & $\begin{array}{l}\text { Between typ } \\
\text { For direction } \\
\text { For all other }\end{array}$ & $\begin{array}{l}\text { nes of sprue } \\
d f=30 \\
\operatorname{rg} d f=46\end{array}$ & $d f^{d}=30$ & & & \\
\hline
\end{tabular}

${ }^{a} t_{95}=1.70$ for $d f=30$.

${ }^{\mathrm{b}} t_{99.5}=2.75$ for $d f=30$.

${ }^{\circ} t_{95}=2.69$ for $d f=46$.

${ }^{d} d f$, degrees of freedom. 
TABLE VII-A

Properties of Significant Variables Indicated in Tables IV and V

\begin{tabular}{|c|c|c|c|c|c|}
\hline \multirow[b]{2}{*}{ UTS } & \multicolumn{3}{|c|}{$17-7$} & \multirow[b]{2}{*}{$\begin{array}{c}\text { Vent } \\
111,000 \\
12,200\end{array}$} & \multirow[b]{2}{*}{$\begin{array}{c}\text { Flat } \\
114,700 \\
14,300\end{array}$} \\
\hline & Spruing & $\begin{array}{c}\vec{X} \\
G\end{array}$ & $\begin{array}{l}\text { Feed } \\
98,700 \\
10,500\end{array}$ & & \\
\hline & Temperature & $\begin{array}{c}\bar{X} \\
G\end{array}$ & $\begin{array}{r}\text { Normal } \\
103,900 \\
14,500\end{array}$ & $\begin{array}{c}\text { Overheat } \\
112,300 \\
12,400\end{array}$ & \\
\hline $0.1 \%$ yield & Spruing & $\begin{array}{c}\bar{X} \\
G\end{array}$ & $\begin{array}{l}\text { Feed } \\
32,000 \\
2,300\end{array}$ & $\begin{array}{l}\text { Vent } \\
30,700 \\
2,700\end{array}$ & $\begin{array}{l}\text { Flat } \\
27,700 \\
3,000\end{array}$ \\
\hline \multirow[t]{2}{*}{ Elongation } & Spruing & $\begin{array}{c}\bar{X} \\
G\end{array}$ & $\begin{array}{l}\text { Feed } \\
3.3 \\
0.77\end{array}$ & $\begin{array}{c}\text { Vent } \\
3.6 \\
1.4\end{array}$ & $\begin{array}{c}\text { Flat } \\
5.3 \\
2.6\end{array}$ \\
\hline & Direction & $\begin{array}{c}\bar{X} \\
G\end{array}$ & $\begin{array}{l}\text { Left } \\
3.1 \\
1.2\end{array}$ & $\begin{array}{c}\text { Right } \\
3.9 \\
1.0\end{array}$ & \\
\hline
\end{tabular}

TABLE VII-B

Properties of Significant Variables Indicated in Tables IV and V

\begin{tabular}{|c|c|c|c|c|c|}
\hline \multirow[b]{2}{*}{ UTS } & \multicolumn{5}{|c|}{ HS-21 } \\
\hline & Spruing & $\begin{array}{c}\bar{X} \\
G\end{array}$ & $\begin{array}{c}\text { Feed } \\
95,300 \\
10,900\end{array}$ & $\begin{array}{c}\text { Vent } \\
109,000 \\
11,100\end{array}$ & $\begin{array}{r}\text { Flat } \\
116,200 \\
6,700\end{array}$ \\
\hline \multirow[t]{2}{*}{$0.1 \%$ yield } & Spruing & $\begin{array}{c}\bar{X} \\
G\end{array}$ & $\begin{array}{c}\text { Feed } \\
72,300 \\
2,700\end{array}$ & $\begin{array}{l}\text { Vent } \\
76,000 \\
4,000\end{array}$ & $\begin{array}{l}\text { Flat } \\
74,700 \\
3,800\end{array}$ \\
\hline & Temperature & $\begin{array}{c}\bar{X} \\
G\end{array}$ & $\begin{array}{r}\text { Normal } \\
75,500 \\
3,500\end{array}$ & $\begin{array}{c}\text { Overheat } \\
73,100 \\
3,700\end{array}$ & \\
\hline \multirow[t]{2}{*}{ Elongation } & Spruing & $\begin{array}{c}\bar{X} \\
G\end{array}$ & $\begin{array}{c}\text { Feed } \\
2.7 \\
1.6\end{array}$ & $\begin{array}{l}\text { Vent } \\
3.9 \\
2.6\end{array}$ & $\begin{array}{l}\text { Flat } \\
5.7 \\
2.6\end{array}$ \\
\hline & Temperature & $\begin{array}{c}\bar{X} \\
G\end{array}$ & $\begin{array}{c}\text { Normal } \\
3.4 \\
2.2\end{array}$ & $\begin{array}{c}\text { Overheat } \\
4.9 \\
2.8\end{array}$ & \\
\hline
\end{tabular}


Table VI gives the results from the $t$-tests. This shows which of the spruing methods had a difference. Also, the factor of direction showed up as significant at the 95\% limit for elongation of 17.7.

TABLE VII-C

Properties of Significant Variables Indicated in Tables IV and V

\begin{tabular}{|c|c|c|c|c|c|}
\hline \multirow[b]{2}{*}{ UTS } & \multirow[b]{2}{*}{ Spruing } & \multicolumn{2}{|c|}{ HS-31 } & \multirow[b]{2}{*}{$\begin{array}{l}\text { Vent } \\
97,400 \\
9,400\end{array}$} & \multirow[b]{2}{*}{$\begin{array}{r}\text { Flat } \\
111,400 \\
8,600\end{array}$} \\
\hline & & $\begin{array}{c}\bar{X} \\
G\end{array}$ & $\begin{array}{c}\text { Feed } \\
81,700 \\
9,400\end{array}$ & & \\
\hline $0.1 \%$ yield & Spruing & $\begin{array}{c}\bar{X} \\
G\end{array}$ & $\begin{array}{l}\text { Feed } \\
62,600 \\
4,000\end{array}$ & $\begin{array}{l}\text { Vent } \\
63,200 \\
2,400\end{array}$ & $\begin{array}{l}\text { Flat } \\
66,700 \\
4,100\end{array}$ \\
\hline & Temperature & $\begin{array}{c}\bar{X} \\
G\end{array}$ & $\begin{array}{r}\text { Normal } \\
66,600 \\
3,600\end{array}$ & $\begin{array}{c}\text { Overheat } \\
61,800 \\
2,700\end{array}$ & \\
\hline Elongation & Spruing & $\begin{array}{l}\bar{X} \\
G\end{array}$ & $\begin{array}{l}\text { Feed } \\
2.2 \\
0.98\end{array}$ & $\begin{array}{l}\text { Vent } \\
4.2 \\
1.2\end{array}$ & $\begin{array}{l}\text { Flat } \\
6.5 \\
2.2\end{array}$ \\
\hline
\end{tabular}

TABLE VIII

Results of $t$-Tests on Analysis of Factor Spruing a

\begin{tabular}{|c|c|c|c|c|c|c|}
\hline \multirow[b]{2}{*}{ Feed } & \multicolumn{2}{|l|}{$\mathrm{U}^{\prime} \mathrm{TS}$} & \multicolumn{2}{|c|}{$0.1 \%$ yield } & \multicolumn{2}{|c|}{ Elongation } \\
\hline & $\begin{array}{l}\text { HS31- } \\
\text { Temp }^{\circ}\end{array}$ & $t=3.54$ & $\begin{array}{l}\text { HS31- } \\
\text { Temp }\end{array}$ & $t=3.99$ & $\begin{array}{l}\text { Not sig- } \\
\text { nificant }\end{array}$ & \\
\hline Vent & $\begin{array}{l}\text { HS31- } \\
\text { Direction }{ }^{\mathrm{b}} \\
\text { HS21- } \\
\text { Direction }^{\mathrm{b}}\end{array}$ & $\begin{array}{l}t=2.55 \\
t=2.03\end{array}$ & $\begin{array}{l}\text { HS31- } \\
\text { Temp }\end{array}$ & $t=5.42$ & $\begin{array}{l}\text { 17-7- } \\
\text { Direction }{ }^{b} \\
\text { HS31- } \\
\text { Direction }^{b}\end{array}$ & $\begin{array}{l}t=2.44 \\
t=2.80\end{array}$ \\
\hline Flat & $\begin{array}{l}\text { 17-7- } \\
\text { Temp }\end{array}$ & $t=1.79$ & $\begin{array}{c}17-7- \\
\text { Temp } \\
\text { HS21- } \\
\text { Temp } \\
\text { HS31- } \\
\text { Temp }^{b}\end{array}$ & $\begin{array}{l}t=2.21 \\
t=3.63 \\
t=2.92\end{array}$ & $\begin{array}{l}\text { HS21- } \\
\text { Temp } \\
\text { HS21- } \\
\text { Wax }^{b}\end{array}$ & $\begin{array}{l}t=2.61 \\
t=1.84\end{array}$ \\
\hline
\end{tabular}

$d f=14$ in all cases.

${ }^{\mathrm{b}} t_{99}=1.76$.

${ }^{\circ} t_{99.5}=2.98$. 
TABLE IX

Properties of Significant Variables Indicated in Table VII

\begin{tabular}{|c|c|c|c|c|c|}
\hline \multicolumn{6}{|c|}{ FEED } \\
\hline \multirow[t]{3}{*}{ UTS } & \multirow[t]{3}{*}{ HS-31 } & \multirow[t]{3}{*}{ Temperature } & & Normal & Overheat \\
\hline & & & $\bar{X}$ & 88,000 & 75,500 \\
\hline & & & $\sigma$ & 7,300 & 6,800 \\
\hline \multirow[t]{4}{*}{$0.1 \%$ yield } & \multirow[t]{4}{*}{ HS-31 } & \multirow[t]{3}{*}{ Temperature } & & Normal & Overheat \\
\hline & & & $\bar{X}$ & 65,500 & 59,800 \\
\hline & & & $\sigma$ & 3,600 & 1,700 \\
\hline & & \multicolumn{2}{|l|}{ VENT } & & \\
\hline \multirow[t]{6}{*}{ UTS } & \multirow{3}{*}{ HS-31 } & \multirow{3}{*}{ Direction } & & Left & Right \\
\hline & & & $\bar{X}$ & 92,300 & 102,600 \\
\hline & & & $\sigma$ & 8,200 & 7,900 \\
\hline & \multirow[t]{3}{*}{ HS-21 } & \multirow[t]{3}{*}{ Direction } & & Left & Right \\
\hline & & & $\bar{X}$ & 103,900 & 114,100 \\
\hline & & & $\sigma$ & 11,100 & 9,000 \\
\hline \multirow{3}{*}{$0.1 \%$ yield } & \multirow[t]{3}{*}{ HS-31 } & \multirow[t]{3}{*}{ Temperature } & & Normal & Overheat \\
\hline & & & $\bar{X}$ & 65,100 & 61,200 \\
\hline & & & $\sigma$ & 1,700 & 1,200 \\
\hline \multirow[t]{7}{*}{ Elongation } & \multirow[t]{3}{*}{$17-7$} & \multirow[t]{3}{*}{ Direction } & & Left & Right \\
\hline & & & $\bar{X}$ & 2.9 & 4.4 \\
\hline & & & $\sigma$ & 1.4 & 0.97 \\
\hline & \multirow[t]{4}{*}{ HS-31 } & \multirow[t]{3}{*}{ Direction } & & Left & Right \\
\hline & & & $\bar{X}$ & 3.5 & 4.9 \\
\hline & & & $\sigma$ & 1.3 & 0.67 \\
\hline & & FLAT & & & \\
\hline \multirow[t]{3}{*}{ UTS } & \multirow[t]{3}{*}{$17-7$} & \multirow[t]{3}{*}{ Temperature } & & Normal & Overheat \\
\hline & & & $\bar{X}$ & 108,200 & 120,700 \\
\hline & & & $\sigma$ & 17,500 & 7,000 \\
\hline \multirow[t]{9}{*}{$0.1 \%$ yield } & $17-7$ & Temperature & & Normal & Overheat \\
\hline & & & $\bar{X}$ & 29,200 & 26,200 \\
\hline & & & $\sigma$ & 3,100 & 2,200 \\
\hline & HS-21 & Temperature & & Normal & Overheat \\
\hline & & & $\bar{X}$ & 77,200 & 72,100 \\
\hline & & & $\sigma$ & 2,200 & 3,200 \\
\hline & HS-31 & Temperature & & Normal & Overheat \\
\hline & & & $\bar{X}$ & 69,200 & 64,200 \\
\hline & & & $G$ & 3,900 & 2,800 \\
\hline Elongation & HS-21 & Temperature & & Normal & Overheat \\
\hline & & & $\bar{X}$ & 4.3 & 2.3 \\
\hline & & & $G$ & 2.1 & 2.2 \\
\hline & HS-21 & Wax & & Dental & Industrial \\
\hline & & & $\bar{X}$ & 5.3 & 6.1 \\
\hline & & & $G$ & 3.1 & 2.2 \\
\hline
\end{tabular}


The values of Multimet are not recorded in these tables because of incomplete data for some of the vent samples. This lack of data resulted from either thread failure during casting or rejection because of hair-line breaks in the threads after casting. Multimet was run separately and the results are presented after the results for the other three alloys. Table VII gives the mechanical properties at each point in Tables V and VI where a factor was found to be significant.

Since the factor spruing in all cases had such a significant effect, a $t$-test analysis was run for each type of spruing. From this type of test, the effects of the remaining variables on a particular type of pattern were studied. The form was the same as before except for the factor spruing. Results are given in Table VIII. The factor temperature becomes more significant and, for vent patterns, direction is significant. Note that the limits on the $t$-values are 99 and 99.5 as compared with the limits of $95-99.5$ in Tables V and VI. Table IX gives the properties at each point in Table VIII where a factor was found to be significant.

Table $\mathrm{X}$ gives the results for Multimet. In general these parallel the results for the other alloys. Table XI gives the overall values for the properties of these four alloys.

TABLE $X$

Results for Multimet: $f$-Tests on Analysis of All Factors

\begin{tabular}{|c|c|c|c|c|c|}
\hline \multicolumn{2}{|c|}{ UTS } & \multicolumn{2}{|c|}{$0.1 \%$ yield } & \multicolumn{2}{|c|}{ Elongation } \\
\hline \multirow[t]{4}{*}{$\begin{array}{l}\text { Spruing } \\
\text { Feed-Flat }\end{array}$} & $f=52.87$ & $\begin{array}{l}\text { Nothi } \\
\text { Signifi }\end{array}$ & & $\begin{array}{l}\text { Spruing } \\
\text { Feed-Flat }\end{array}$ & $f=21.39$ \\
\hline & $\begin{array}{l}\text { For Sprui } \\
f_{99}=7.56\end{array}$ & g degrees & freedom & $1=1 / 30$ & \\
\hline & UTS & Spruing & $\begin{array}{c}\text { Feed } \\
66,500 \\
10,900\end{array}$ & $\begin{array}{c}\text { Flat } \\
90,200 \\
7,200\end{array}$ & \\
\hline & Elongation & Spruing & $\begin{array}{c}\text { Feed } \\
8.4 \\
4.5\end{array}$ & $\begin{array}{r}\text { Flat } \\
16.5 \\
5.4\end{array}$ & \\
\hline
\end{tabular}


TABLE XI

Mechanical Properties when Variables are Considered as One Group

\begin{tabular}{|c|c|c|c|c|c|}
\hline & $\begin{array}{l}\text { Total no. } \\
\text { of samples } \\
\text { cast }\end{array}$ & & $\begin{array}{c}\text { UTS, } \\
\text { psi }\end{array}$ & $\begin{array}{c}0.1 \% \\
\text { yield, } \\
\text { psi }\end{array}$ & $\begin{array}{c}\text { Elonga- } \\
\text { tion, } \\
\text { in./in. }\end{array}$ \\
\hline \multirow[t]{3}{*}{$17-7$} & 40 & $\begin{array}{l}\text { No. samples } \\
\text { used in } \\
\text { analysis }\end{array}$ & 39 & 39 & 37 \\
\hline & & $\bar{X}$ & 107,300 & 30,800 & 3.7 \\
\hline & & $\sigma$ & 13,800 & 3,000 & 0.9 \\
\hline \multirow[t]{3}{*}{ HS-21 } & 40 & $\begin{array}{l}\text { No. samples } \\
\text { used in } \\
\text { analysis }\end{array}$ & 40 & 40 & 40 \\
\hline & & $\bar{X}$ & 105,500 & 74,100 & 4.1 \\
\hline & & $\sigma$ & 13,500 & 3,700 & 2.6 \\
\hline \multirow[t]{3}{*}{ HS-31 } & 40 & $\begin{array}{l}\text { No. samples } \\
\text { used in } \\
\text { analysis }\end{array}$ & 39 & 39 & 39 \\
\hline & & $\bar{X}$ & 92,800 & 63,300 & 3.9 \\
\hline & & $\sigma$ & 13,300 & 3,300 & 2.2 \\
\hline \multirow[t]{3}{*}{ Multimet } & 40 & $\begin{array}{l}\text { No. samples } \\
\text { used in } \\
\text { analysis }\end{array}$ & 33 & 32 & 33 \\
\hline & & $\bar{X}$ & 75,600 & 42,900 & 9.6 \\
\hline & & $\sigma$ & 12,900 & 2,500 & 4.0 \\
\hline
\end{tabular}

\section{DISCUSSION}

Although these alloys were cast with a variation in procedure, they were not cast following a procedure which would optimize their properties. Therefore, in some instances, the results were not what would normally be expected with the alloy. For example, $17-7$ is a heat-treatable alloy and has usual values twice those in this report. Table XII shows the values usually given for these alloys. A comparison with Table XI shows that the properties obtained in this study were similar for tensile strengths. However, the values for elongations average much lower. This may be due to improper feeding with various spruing designs. Poor feeding results in microporosity. This defect will have a greater effect on elongation than on ultimate tensile strength. 
Table XII

Mechanical Properties of Alloys Under Optimum Conditions

\begin{tabular}{lccc}
\hline & UTS & Yield strength & Elongation \\
\hline $17-7^{\mathrm{a}}$ & 199,000 & 188,000 & 16.3 \\
HS-2 $1^{\mathrm{b}}$ & 103,000 & 82,000 & 8 \\
& & $(0.2 \%$ offset $)$ & $\left(\%\right.$ in $\left.2^{\prime \prime}\right)$ \\
HS-31 & 110,000 & 80,000 & 8 \\
Multimet $^{d}$ & 98,000 & 57,800 & 27 \\
& & $(0.2 \%$ offset $)$ & \\
\hline
\end{tabular}

a Viking Steel Company.

b Engineering Alloys Digest, Inc., May 1953, revised November 1960.

- Investment Casting (brochure) Arwood Corporation 1964, p. 24.

¿ Multimet Alloy (brochure) Union Carbide, Stellite Div., September 1966, p. 7.

The variables presented in Table IV are considered as being influential on the properties of the dental casting. However, Table $\mathrm{V}$ shows that of all the variables, spruing design is most important. Samples made by the feed method had the lowest property values. These values were improved for the vent method. However, the flat method of spruing consistently gave the best properties.

Since the flat method consistently gave improved properties for all the alloys, this method is truly a better way of spruing the samples. This method is also the most desirable from the clinical viewpoint. Not only is a sound casting obtained, but the amount of metal used to make the test sample is the same as that for the actual dental casting.

This investigation was supported by USPHS Grant DE-02017 from the National Institute of Dental Research, National Institutes of Health, Bethesda, Maryland.

\section{References}

1. F. A. Peyton, D. H. Anthony, K. Asgar, G. T. Charbeneau, R. G. Craig, and G. E. Myers, Restorative Dental Materials, 2nd ed., C. V. Mosby, St. Louis, 1964.

2. R. Earnshaw, Brit. Dent. J., 108, 389, 429 (1960).

3. E. R. Dootz, R. G. Craig, and F. A. Peyton, J. Pros. Dent., 15, 679 (1965).

4. T. J. Carter and J. N. Kidd, Brit. Dent. J., 118, 383 (1965).

5. R. Earnshaw, Austral. Dent. J., 3, 159 (1958).

6. R. Earnshaw, Brit. Dent. J., 109, 238 (1960). 
7. K. Asgar and F. A. Peyton, J. Dent. Res., 40, 63 (1961).

8. F. C. Allan and K. Asgar, J. Dent. Res., 45, 1516 (1966).

9. K. Bungardt and H. Vollmer, Stahl Eisen, 82, 401 (1962).

10. R. F. Decker, J. P. Rowe, and J. W. Freeman, "Role of Oxygen and Nitrogen in Vacuum and Air-Melting of a Complex Heat-Resistant Alloy," paper presented at AIME Annual Meeting, San Francisco, 1959.

11. A. Dunlop, Metal Ind., 96, 169 (1960).

12. J. A. Miller and F. S. Badger, "The Future of Vacuum Melted Alloys in the Investment Casting Field," paper presented before the Investment Casting Institute of Muskegon, Michigan, 1958.

13. H. Griffiths and R. E. Phelps, Metallurgiqa, 68, 3 (1963).

14. D. C. Ludwigson and F. R. Morral, A Summary of Comparative Properties of Air-Melted and Vacuum-Melted Steels and Superalloys, DMIC Report No. 128, 1960, 144 pp., PB151085.

15. R. Earnshaw, Brit. Dent. J., 110, 341 (1961).

16. D. F. Taylor, W. A. Leibfritz, and A. G. Adler, J. Amer. Dent. Assoc., 56, $343(1958)$.

17. T. J. Carter and J. N. Kidd, Brit. Dent. J., 118, 431 (1965).

18. H. J. Harcourt, Brit. Dent. J., 110, 43 (1961).

19. H. J. Harcourt, Brit. Dent. J., 116, 475 (1964).

20. S. T. Wlodek, ASM Trans., 56, 287 (1963).

21. J. W. Weeton and R. A. Signorelli, ASM Trans., 47, 815 (1955).

22. K. Lobl, J. Jezek, and H. Tuma, Rev. Metallurgie, 56, 324 (1959).

23. A. K. Wolff, E. E. Underwood, R. E. Maringer, and G. K. Manning, The Effects of Solute Elements on the Strength Properties of Iron- and Co-Base Alloys. WADC Tech. Rept. 58-258, April 1959, 63 pp. PB161043.

24. H. Griffiths and R. E. Phelps, Metallurgia, 69, 203 (1964).

25. A. R. Elsea and C. C. McBride, AIME Trans., 188, 154 (1950).

26. W. J. Pennington, Metal Progr. 73, 82 (1958).

27. J. A. Van Echo and W. F. Simmons, Mechanical and Physical Properties of Three Superalloys; $M A R-M 200, M A R-M 302$, and $M A R-M 322$, DMIC Memo. 193, 27 pp., 1964.

28. K. Asgar and F. C. Allan, J. Dent. Res., 47, 189 (1968).

29. E. M. Prosen, "Stainless Alloys Containing Gallium," U.S. Pat. 3,134,670 (1964).

Received July 9, 1968 